\title{
Poučevanje in učenje italijanščine na narodnostno mešanem območju Slovenske Istre
}

\author{
(1) \\ Metka Malčič, Nives Zudič Antonič \\ Fakulteta za humanistične študije, Univerza na Primorskem \\ metka.malcic@fhs.upr.si \\ nives.zudic.antonic@fhs.upr.si
}

Nel presente saggio vengono presentati i risultati di alcune ricerche fatte dal Dipartimento di Italianistica della Facoltà di Studi Umanistici dell'Università del Litorale e alcuni esempi di buone pratiche. Le ricerche sono state effettuate partendo dalle esigenze che si sono verificate nelle scuole del territorio bilingue dell'Istria slovena.

Parole chiave: apprendimento/insegnamento della lingua italiana, lingua della minoranza, ricerche, plurilinguismo, diversità

V prispevkuso predstavljeni izsledkiraziskav, kijihje Oddelekzaitalijanistiko Fakultetezahumanistične študije Univerze na Primorskem izvedel v desetih letih svojega obstoja ter nekaj predlogov za delo v razredu. Raziskave so bile izvedene na podlagi potreb, ki so se pokazale v šolah na narodnostno mešanem območju Slovenske Istre.

Ključne besede: poučevanje/učenje italijanskega jezika, manjšinski jezik, raziskave, večjezičnost, različnost

$\mathrm{N}$ a narodnostno mešanem območju Slovenske Istre je učenje in poučevanje italijanskega jezika kot manjšinskega jezika vedno aktualna, a tudi posebej občutljiva tema, ki se je je potrebno lotevati z veliko mero odgovornosti in sistematičnosti. Spremembe v družbi vse vpletene v vzgojo in izobraževanje nenehno spodbujajo k temu, da sledijo odkritjem in izsledkom raziskav ter novostim na različnih področjih človekovega udejstvovanja. Na podlagi tega si na svojih področjih delovanja postavljajo nove cilje in iščejo inovativne poti za njihovo uresničevanje.

Globalizacija in sodobni migracijski tokovi ter posledično nove razmere nas $\mathrm{v}$ večjezikovnih in večkulturnih družbah postavljajo pred nove izzive in nam v večjezikovnih in večkulturnih razredih določajo nove cilje, ki se lahko uresničujejo le s sledenjem novih smernic za poučeva- nje in učenje jezikov, s pripravo ustreznih gradiv in s permanentnim izobraževanjem učiteljev in drugih zaposlenih na področju vzgoje in izobraževanja.

$\mathrm{Na}$ območju Slovenske Istre, ki je uradno dvojezična, v resnici pa že stoletja večjezična in večkulturna, se veliko raziskovalcev/k posveča raziskovanju dvojezičnosti, večjezičnosti in medkulturnosti in razvija nove modele in strategije za učenje in poučevanje jezika in razvijanje medkulturne sporazumevalne zmožnosti.

Oddelek za italijanistiko Fakultete za humanistične študije Univerze na Primorskem (v nadaljevanju FHŠ UP) svoje poslanstvo uresničuje preko povezovanja $\mathrm{z}$ okoljem in $\mathrm{v}$ sodelovanju $\mathrm{z}$ institucijami, ki delujejo na področju učenja in poučevanja, promocije in zaščite italijanskega jezika v Sloveniji, v Italiji, pa tudi v nekaterih drugih evropskih državah, kjer se pouču- 
jejo manjšinski jeziki, organizira izobraževanja za učitelje in sodeluje pri raziskavah in pripravi učnih gradiv za šole vseh stopenj, kjer se poučuje italijanski jezik kot materni jezik (Ji), drugi jezik $\left(\mathrm{J}_{2}\right)$ in tuji jezik (TJ).

\section{Teoretski okvir: dvojezični model} izobraževanja v Slovenski Istri, vzgoja za dvojezičnost in večjezičnost, razvijanje medkulturne sporazumevalne zmožnosti Dvojezični model izobraževanja v Slovenski Istri

V Slovenski Istri delujejo vzgojno-izobraževalne ustanove v slovenskem in italijanskem učnem jeziku, v vseh šolah pa se poučuje tudi drugi jezik, tki. jezik okolja. Na osnovnih in srednjih šolah sta oba jezika kot druga, nematerna jezika učencev, obvezna učna predmeta.

Za uresničevanje čim ustreznejšega modela dvojezičnega izobraževanja so bile v preteklosti izvedene različne raziskave, tako na ravni sistema kot na ravni vsebin, organizacije pouka in didaktike. Cilj raziskav je bil zagotovitev takega modela, ki bi uresničeval izbrane izobraževalne in socializacijske cilje učencev o sobivanju različnih jezikovnih/etičnih skupnosti v mešanem okolju. Rezultate raziskav lahko strnemo $\mathrm{v}$ tri sklope:

I) jezikovno znanje prvega in drugega jezika ( $\mathrm{J}_{\mathrm{I}}$ in $\left.\mathrm{J}_{2}\right)$,

2) védenje o sobivajoči narodni skupnosti,

3) raziskovanje stališč.

Za ugotavljanje učinkovitosti modela so se raziskave opirale predvsem na Cumminsov interakcijski model dvojezičnega izobraževanja, ${ }^{\mathrm{T}}$ Gardnerjev socialno izobraževalni model ${ }^{2}$ in $\mathrm{Ba}-$ kerjev model stališč do dvojezičnosti. ${ }^{3}$

I Jim Cummins, Language, Power and Pedagogy. Bilingual Children in the Crossfire (Clevendon: Multilingual Matters, 200I).

2 Robert C. Gardner, Social psychology and second languagelearning. The role of attitudes and motivation (London: Edward Arnold, 1985).

3 Colin Baker, Attitudes and Language (Clevendon: Multilingual Matters, 1992)
Rezultati nekaterih raziskav so pokazali, ${ }^{4}$ da so pri poučevanju italijanskega jezika kot drugega jezika prisotne naslednje težave: neustrezni učbeniki, premalo motivacije za učenje jezika, preveliki razredi ( 28 učencev, na srednjih šolah tudi nad 30), neustrezne učilnice (predvsem na srednjih šolah) in neustrezne metode poučevanja (ponavadi tradicionalno frontalno učenje), premalo uporabljane informacijske tehnologije, premalo sredstev za promocijo jezika v Sloveniji s strani Italije.

\section{Vzgoja za dvojezičnost in večjezičnost}

Pot do dvojezičnosti in večjezičnosti je postopna in izjemno zapletena. Uspešna dvojezična oziroma večjezična vzgoja je rezultat različnih dejavnikov, notranjih in zunanjih. Med notranje dejavnike uvrščamo nevro-cerebralni in psihološki vidik. Prvi vpliva na razvoj jezikovne inteligence in se odraža predvsem v stopnji razvitih sposobnosti in zmožnosti. Psihološki vidik pa vključuje učenčevo samopodobo, interese, pa tudi odnos, ki ga ima do večjezičnosti in medkulturnosti. Med zunanje dejavnike pa spadajo: odnos učenčeve družine do večjezičnosti, učno okolje, vpliv družbe, demografska sestava prebivalstva in njegova jezikovna komponenta.

\section{Razvijanje medkulturne sporazumevalne zmožnosti}

Razvijanje medkulturne sporazumevalne zmožnosti je druga pomembna sestavina jezikovnega kurikula in je nedvomno temeljna komponenta poučevanja/učenja jezika $\mathrm{v}$ našem prostoru, zato smo se preko raziskav želeli posvetiti tudi tej komponenti. Različne spremembe v družbi spreminjajo našo družbo v večkulturno, zato se razvijanje medkulturnega zavedanja kaže kot vedno bolj pomembno. »Če želimo preseči večkulturnost in narediti družbo medkulturno, se moramo načrtno in sistematično posvečati razvijanju medkulturnega zavedanja že na prvi stopnji

\footnotetext{
Mednarodna projekta Comenius 2.I »Info «- opredelitev modela za usposabljanja učiteljev v večjezičnih okoljih (2004-2007) in mednarodna projekta Comenius 2.I »Promocija manjšinskih jezikov v večjezičnih območjih s poudarkom na izobraževanju učiteljev in učiteljic « (2003-2006), nosilka Nives Zudič Antonič.
} 
vzgojno-izobraževalnega sistema in jo razvijati skozi celoten izobraževalni proces. Temeljno poslanstvo medkulturne vzgoje je namreč razvijanje sposobnosti sobivanja $\mathrm{z}$ ljudmi različnih jezikovnih in kulturnih izvorov, tako z ljudmi, ki že ves čas živijo $v$ našem okolju (avtohtone in druge etnične skupine), kot z ljudmi, ki so se nam pridružili v zadnjem času. Poznavanje, razumevanje in sprejemanje drugačnosti omogoča človeku, da sprejema prisotnost več kultur v lastnem prostoru kot vrednoto in kot možnost za nadaljnji razvoj svoje osebnosti.«s

Z uvajanjem medkulturne vzgoje tudi v dokumente, ki urejajo področje vzgoje in izobraževanja, se Republika Slovenija približuje jezikovni politiki Evropske unije (EU) in uresničuje ukrepe, zapisane v dokumentih EU ter Sveta Evrope (SE). ${ }^{6}$ Tak primer so Priporočila št. R (98) $6 \mathrm{Mi}$ nistrskega sveta državam članicam glede modernih jezikov (1998) ${ }^{7}$, ki vladam držav članic priporočajo, da $\mathrm{v}$ okviru razpoložljivih sredstev in v skladu z njihovo ustavno ureditvijo ter šolskim sistemom na dvojezičnih in večkulturnih območjih sledijo politiki vzgoje in izobraževanja, ki:

- upošteva predpise Evropske listine o regionalnih in manjsinskih jezikih (ETS št. I48, 1992), in ukrepe Okvirne konvencije SE o varstvu narodnih manjsin (1995), ${ }^{9} \mathrm{v}$ katerih so opredeljeni zaželeni parametri izvajanja

Lafayette, str. 55, navedno po: Nives Zudič Antonič in Anja Zorman, ur., Prepletanja : didakticni prirocnik za medkulturno vzgojo brez meja (Koper: Univerza na Primorskem, Znanstveno-raziskovalno središče, Univerzitetna založba Annales, 20 4 b). Dostopno na: http://www.eduka-itaslo.eu/, 5 .

Robert C. Lafayette, "Integrating the Teaching of Culture into the Foreign Language Classroom," v Toward a New Integration of Language and Culture, ur. A.J. Singerman, 47-62 (Middlebury: VT, The North-east Conference, 1997).

6 Poleg priporočil, ki jih omenjava v besedilu, sta EU in Svet Evrope oblikovala različna besedila, pri tem med pomembnejše publikacije s področja razvijanja medkulturnosti prav gotovo prištevamo Belo knjigo o medkulturnem dialogu (Strasbourg: Svet Evrope, 2008).

Recommendation No.R (98) 6 of the Committee of Ministers to Member States concerning Modern Languages (1998).

8 Evropske listine o regionalnih in manjsinskih jezikih, ETS št. I 48 (Strasbourg: Svet Evrope 1992). Dostopno na: http://www.svetevrope. si/sl/dokumenti_in_publikacije/konvencije/ı48/

9 Okvirne konvencije SE o varstvu narodnih manjsin (Strasbourg: Svet Evrope, 1995). Dostopno na: http://www.svetevrope.si/sl/dokumenti_in_publikacije/konvencije/I57/ politike glede regionalnih ali manjšinskih jezikov in kultur (22.I);

enakovredno upošteva in spoštuje vse jezike in kulture posameznega večjezičnega in večkulturnega območja na način, ki otrokom vseh narodnih skupnosti omogoča razvijanje govorne in pisne komunikacije v jeziku svoje skupnosti, ter obenem omogoča razvijanje razumevanja in spoštovanja jezika in kulture druge narodne skupnosti (22.2);

- na območjih, ki ponujajo dvojezično šolanje, razvija pristno medkulturno zavedanje in zagotovi možnosti za učenje ostalih jezikov (22.3);

- na obmejnih območjih omogoča in spodbuja učenje jezikov sosedskih držav (24).

Če želimo razumeti drugo kulturo v svojem okolju oziroma tujo kulturo v tujem okolju, je potrebno te kulture primerjati s svojo lastno. Primerjava kultur in odkrivanje drugačnosti nam pomaga razmišljati o svoji kulturi in jo bolj poglobljeno spoznavati ter razvijati zavedanje o drugi/h kulturi/ah in jo/jih sprejemati. $V$ šoli moramo torej stremeti $\mathrm{k}$ razvijanju kulturnih modelov kot najmanjših enot analize kulture. Učence obenem vzgajamo za opazovanje kulture in za opazovanje sprememb, ki so v sodobnih družbah zelo pogoste.

Ustrezna in učinkovita medkulturna vzgoja mora biti skrbno načrtovana; za razvijanje medkulturnega zavedanja pa ni potrebnega veliko teoretičnega znanja, saj je le-to pogojeno predvsem $\mathrm{z}$ dejavnostjo in ne zgolj z opazovanjem, pozornim poslušanjem in pomnjenjem večje količine podatkov v kratkem času. Aktivna dejavnost učenca se lahko odvija $\mathrm{z}$ različnimi oblikami dela, kot so skupinsko delo, projektno delo, integrirani pouk ipd. Za ustrezno razvijanje medkulturnosti v šoli je potrebno na novo opredeliti delo in metodologijo pedagoškega dela. Medkulturna vzgoja se lahko izvaja pri kateremkoli 
predmetu, pri katerikoli vsebini in v okviru učnih načrtov prav vseh predmetov. ${ }^{\text {Io }}$

\section{Sodobno poučevanje jezikov: izzivi za prihodnost (vzgoja za večjezičnost in diferenciacija)}

Poučevanje italijanskega jezika kot manjšinskega jezika ima na območju Slovenske Istre dolgoletno tradicijo, na katero smo lahko upravičeno ponosni. Časi in razmere v družbi (migracijski procesi, globalizacija, vloga in pomen angleškega jezika,...) so vplivali tudi na učenje in poučevanje italijanskega jezika in na delo v razredu, saj se je spremenil odnos do jezika, njegova vloga in znanje le-tega. Za vse več učencev v šolah z italijanskim učnim jezikom ta mnogokrat ni več materni jezik (JI), v šolah s slovenskim učnim jezikom pa za vse več učencev ni več jezik okolja $\left(\mathrm{J}_{2}\right)$, ampak tuj jezik (TJ).

Sprašujemo se, kakšen pouk organizirati, če želimo slediti ciljem sodobne šole, ki so tudi cilji sodobne družbe (med šolo in družbo vlada dialektičen odnos: šola naj bi izobraževala in vzgajala na način, ki ga velevajo potrebe družbe). Šola kot odraz širše družbene skupnosti učiteljem nalaga, da uresničujejo izobraževalne in vzgojne cilje, a učitelji so v heterogenih razredih postavljeni pred zelo zahtevno in kompleksno situacijo, saj morajo, če želijo motivirati svoje učence, biti

Io Primerjaj Nives Zudič Antonič, »Italijanščina kot prvi jezik v manjšinskih šolah Slovenske Istre, « v Izobraževanje za dvojezičnost v kontekstu evropskih integracijskih procesov: ucinkovitost dvojezičnih modelov izobraževanja v etnično mešanih okoljih Slovenije, ur. Lucija Čok (Koper: Univerza na Primorskem, Znanstveno-raziskovalno središče, Založba Annales, 2009); Nives Zudič Antonič in Anja Zorman, »Izobraževanje učiteljev in medkulturna vzgoja, «v $V$ zgajati k razlicnosti: interdisciplinarna primerjalna raziskava med Italijo in Slovenijo, ur. Norina Bogatec in Nives Zudič Antonič (Koper: Univerza na Primorskem, Znanstveno-raziskovalno središče, Univerzitetna založba Annales, 20r 4a); Neva Čebron, »An Investigation into Intercultural Communication Issues in High School Curricula in Italy, Slovenia and Turkey,« Journal of foreign language teaching and applied linguistics (2014).

II Glej Čok, Izobraževanje za dvojezičnost v kontekstu europskih integracijskih procesov. Nives Zudič Antonič, »Razvijanje medkulturne in sporazumevalne zmožnosti pri pouku tujega/drugega jezika v Sloveniji, « v Brez spopada: kultur, spolov, generacij, ur. Veronika Tašner et al. (Ljubljana: Pedagoška fakulteta, 2009). še bolj predani svojemu delu; ${ }^{\mathrm{I2}}$ potrebujejo nova, drugačna, sodobna gradiva; $z$ učenci in s sodelavci morajo vzpostavljati uspešne medsebojne odnose; povezovati se morajo $\mathrm{z}$ okoljem in iz njega črpati informacije, odgovore, spodbude in izzive. ${ }^{\mathrm{I3}}$

Sodobni pouk jezika temelji na komunikativnem pristopu in razvijanju medkulturne sporazumevalne zmožnosti: pouk je osredinjen na učenca in izhaja iz učenčevih komunikacijskih potreb; usmerjen je na proces učenja in upošteva različne sloge učenja; upošteva dejstvo, da so jezik, kultura in družba povezani in da je torej posameznikov mikrokozmos odraz družbenega makrokozmosa; med učitelji in učenci vladajo enakopravni odnosi, kar pri učencu spodbuja in krepi odgovornost in samostojnost; pouk vključuje rabo informacijske komunikacijske tehnologije (IKT).

Prva učenčeva potreba pri usvajanju jezika in vzgoji za različnost je sprejemanje vrstnikov in učiteljev. Učitelji naj bi v prvi vrsti zagotavljali mirno, varno in spodbudno okolje, ki ugodno vpliva na učenje. ${ }^{14}$ Zanimiv in skrbno pripravljen pouk, ki je v skladu s starostjo, potrebami, interesi, predznanjem in sposobnostmi učencev, bo dodatno prispeval ne le $\mathrm{k}$ motivaciji, ampak tudi $\mathrm{k}$ razvijanju samostojnosti in sprejemanju odgovornosti za lastno učenje. $V$ varni in na spoštljivih odnosih temelječi šolski skupnosti bo učenec lahko nadgrajeval svoje znanje, razvijal talente in potencial, kar bo prispevalo tudi $\mathrm{k}$ njegovi osebnostni rasti.

Zaradi naštetih razlogov je potrebno v poučevanje/učenje jezikov vnesti spremembe. V vseh metodoloških pristopih, ki so bili v veljavi v preteklosti, lahko najdemo konstante, katerim se je $\mathrm{v}$ različnih obdobjih dajalo različen pomen. To

\footnotetext{
I2 Nives Zudič Antonič in Anja Zorman, »Izobraževanje učiteljev in medkulturna vzgoja, « V Vzgajati k razlićnosti: interdisciplinarna primerjalna raziskava med Italijo in Slovenijo, ur. Norina Bogatec in $\mathrm{Ni}$ ves Zudič Antonič (Koper: Univerza na Primorskem, Znanstveno-raziskovalno središče, Univerzitetna založba Annales, 2014a).

I3 Nives Zudič Antonič in Metka Malčič, »Bisogni emersi, « v Progetto Info: La ricerca e il modello di formazione europeo, ur. Olimpia Rasom (Bolzano: Istitut Pedagogich Ladin, 2007b).

I4 Glej Anna Ciliberti, Glottodidattica: per una cultura dell'insegnamento linguistico.
} 
so npr.: aktivna, direktna in ustna metoda, metoda imitacije, induktivna metoda, metoda ponavljanja,... Druga sledljiva konstanta v metodoloških pristopih, ki so si med seboj tudi precej različni, je tki. osnoven didaktičen proces. Metodološki pristopi so odvisni od zunanjih in notranjih faktorjev, ki vplivajo na izobraževalni proces. Zunanji dejavniki vpliva so predvsem na področju kulturnega in političnega ozračja določenega zgodovinskega obdobja $\mathrm{v}$ posamezni državi, ki do neke mere določa zahteve izobraževalnih ustanov. Notranja dejavnika pa sta predvsem razvoj posameznega predmetnega področja in pozornost, ki jo teoretiki poučevanja jezika in avtorji didaktičnih gradiv posvečajo različnim komponentam procesa poučevanja/učenja.

Na našem območju sta zunanja razloga aktualnih sprememb predvsem dva: evropeizacija nacionalnega šolskega sistema, ki se želi uskladiti z drugimi državami Evropske skupnosti (Skupni Evropski referenčni okvir, temeljni dokument za vse države članice Evropske skupnosti za pripravo letnega delovnega načrta, za pripravo učnih načrtov za jezike, za izpite, za učbenike ...); po drugi strani pa drugačna populacija v obveznih osnovnih šolah, ki se je spremenila zaradi migracijskih procesov v naši državi in zaradi katerih je potrebno upravljati procese jezikovnih stikov med slovenskim in italijanskim jezikom/kulturo in med jeziki/kulturami priseljencev. ${ }^{\text {I5 }}$

Notranji razlogi za metodološke spremembe pa izhajajo neposredno iz razvoja področij različnih ved, ki so pomembna za poučevanje predvsem gre tu za področje poučevanja jezikov in pozornost, ki jo različni udeleženci posvečajo različnim komponentam procesa poučevanja in učenja. Sodobna teorija poučevanja tujih jezikov se osredotoča predvsem na posameznika, na različne načine, na katere se posameznik uči jezikovnih vsebin, na različno motivacijo, predznanje in izkušnje ter strategije za učenje.

Zaradi naštetih posebnosti je potrebno organizirati metodološko diferenciacijo, ki pred-

I5 Smernice za vkljućevanje otrok priseljencev v vrtec in sole (Ljubljana: Zavor RS za šolstvo 2012). Dostopno na: http://eportal.mss.edus.si/ msswww/programi2015/programi/media/pdf/smernice/cistopis_Smernice_vkljucevanje_otrok_priseljencev.pdf. stavlja konec za globalno didaktično koherenco. Tako prehajamo v obdobje eklekticizma, kjer se prepletajo različne problematike heterogene narave, ki dobivajo središčno vlogo. Središčne diskusije pri poučevanju/učenju tujih jezikov se tako vrtijo okrog didaktike večjezičnosti in diferenciacije pouka.

Vzgoja za večjezičnost spodbuja učenje več jezikov in si zastavlja več ciljev: kulturne, jezikovne in kognitivne. Diferencirana didaktika pa se ukvarja s številnimi faktorji diferenciacije, ki so prisotni pri poučevanju/učenju: $\mathrm{z}$ diferenciacijo psiho-socialnega vidika učencev in učiteljev in statusa vsakega posameznega jezika. ${ }^{16}$

\section{Didaktika večjezičnosti:}

kulturni, jezikovni, kognitivni cilji

Po priporočilih Evropske skupnosti, bi moral vsak državljan poznati štiri jezike Evropske skupnosti: poleg maternega jezika še tri evropske jezike, na različnih nivojih. Da bi evropski državljan postal večjezičen, bi morali od didaktike določenega jezika preiti na didaktiko jezikov, oziroma še bolje, na didaktiko večjezičnosti.

Cilji, ki naj bi jih dosegali v večjezičnih in multikulturnih razredih, so kompleksni in jih lahko razdelimo na tri skupine:

a) kulturni cilji: vzgoja za medkulturnost in za različnost; razvijanje sposobnosti razumevanja in interpretacije drugih kultur v primerjavi s svojo; ti cilji zamenjujejo cilj komunikativne zmožnosti, kot so ga pojmovale metodologije, ki so bile v veljavi pred tem in se nanaša na upravljanje procesov pri jezikovnih stikih med različnimi jeziki/kulturami

b) jezikovni cilji: razvijanje poznavanja jezikov in vsaj nekaterih funkcijskih zvrsti (odvisno od stopnje znanja jezika in zastavljenih ciljev);

c) kognitivni cilji: razvijanje fleksibilnosti, radovednosti, zmožnosti prilagajanja in usvajanja strategij za učenje jezika na različnih stopnjah.

I6 Ciliberti, Glottodidattica. 
Kulturni cilji:

Medkulturno vzgojo in vzgojo za različnost je potrebno razvijati pri vseh predmetih, saj le tako lahko uresničujemo interdisciplinarnost, vzgojo za razumevanje, za upravljanje kompleksnih pojavov in za reševanje konfliktov. Cesari ${ }^{17}$ razlaga, da gre za $\gg$ pojav, ki ga je potrebno obravnavati v vsej svoji kompleksnosti in ga uresničevati preko globalnih pedagoških projektov.«

Jezikovni cilji:

Za doseganje jezikovnih ciljev je nujno potrebna diferenciacija učnih načrtov in diferenciran pouk, pri katerem nam je lahko v veliko pomoč informacijska komunikacijska tehnologija (IKT) in integrirano učenje jezikov (CLIL). Poleg tega je potrebno diferencirati zmožnosti pri usvajanju različnih jezikov in pri doseganju različnih spretnosti.

Kognitivni cilji:

Glede na to, da je temeljni cilj sodobnega poučevanja jezikov "učiti se učiti", je potrebno pri učencih razvijati in krepiti zavedanje vloge, ki jo imajo kot učenci, razvijati spretnost samostojnega učenja in zavedanje njegovega pomena, razvijati odgovornost do učenja, kritično razmišljanje in samovrednotenje. ${ }^{18}$

Diferenciacija pouka oziroma koncept pedagoške variacije predpostavlja, da si v razredu zastavljamo za različne učence različne cilje, izbiramo različne vsebine, naloge, dejavnosti in uporabljamo različne pristope, tehnike, pripomočke in upoštevamo različen ritem dela (v skladu z osebnostjo, interesi, motivacijo, cilji, kulturo, navadami, uspehom in stopnjo znanja jezika posameznega učenca). Povezovanje različnih področij, pogledov, ugotovitev »je praktičen odgovor /.../ na drugačnost, heterogenost, spremenljivost, nestabilnost, množičnost $\ll .{ }^{19}$

\footnotetext{
I7 Vittoria Cesari Lusso, "La dimensione interculturale nell'educazione: riflessioni e riferimenti per l'azione pedagogica," v L'educazione interculturale, ur. Fulvio Poletti (Firenze: La Nuova Italia, 1992), Ioo.

I8 Ciliberti, Glottodidattica.

19 Louise Dabène et al., Variations et rituels en classe de langue (Paris: Hatier-Crédif, 1990), 96.
}

Izhajajoč iz Evropskega referenčnega okvi$\mathrm{ra},{ }^{20}$ učenci ne morejo doseči pričakovanih kompetenc iz kurikula enkrat za vselej, saj gre za fleksibilne kompetence, ki se uresničujejo pri uporabi jezika/jezikov $\mathrm{v}$ realnih komunikacijskih situacijah, za kar je potrebna sposobnost prilagajanja in dogovarjanja. Različni konteksti, raznoliki problemi, ki jih moramo reševati, nove, nepredvidljive situacije, $\mathrm{v}$ katerih se znajdemo, od nas zahtevajo ustrezno soočanje. V opisanih situacijah je potrebno znati uporabljati/prilagajati jezik, torej moramo usvojiti kreativno, dinamično jezikovno zmožnost. Če za komunikacijo znamo uporabljati enega ali več jezikov, to pomeni, da moramo poznati aktivne strategije, biti moramo odprti, fleksibilni, prilagodljivi. Pripravljeni se moramo znati učiti, kar pomeni, da moramo:

- usvojiti dinamično poznavanje stvari (jezikovno in kulturno znanje)

znati delati določene stvari s pomočjo ustreznih strategij

- $\quad$ znati biti, biti vešči na kognitivni, čustveni in kulturni ravni (v Referenčnem okviru ${ }^{2}$ tki. eksistencialna kompetenca).

\section{Izobraževanje učiteljev/-ic}

Da bi razvijali vse naštete kompetence, je ključno ustrezno izobraževanje učiteljev/ic. Učitelj/ ica, ki poučuje jezik v večkulturnem in večjezičnem razredu, mora $v$ prvi vrsti odlično poznati jezik, katerega poučuje, opremljen/a pa mora biti tudi z novimi znanji s področja poučevanja in učenja jezika, zato se mora permanentno izobraževati na področju jezika, učenja in poučevanja le-tega. Učitelj/ica, ki želi uspešno organizirati pouk, ki je osredinjen na učenca, mora biti opremljen/a z ustreznim znanjem in védenjem, iz okolja pa mora dobivati ustrezne spodbude in pomoč. Za sodobnega/o učitelja/ico tako ne za-

20 Council of Europe, Common European Framework of Reference for Languages: Learning, Teaching, Assessment (Cambridge: University Press, 2001).

2 I Council of Europe, Common European Framework of Reference for Languages: Learning, Teaching, Assessment (Cambridge: University Press, 200I). 
doščajo več tradicionalni seminarji in bivanje $\mathrm{v}$ tujini, ampak se mora soočati z raznolikimi situacijami, v katerih uporablja jezik, se preizkuša in deluje v lokalnem, pa tudi nacionalnem, čezmejnem in mednarodnem okolju. Le široko izobražen/a učitelj/ica bo kos nalogam, pred katere ga/jo postavlja sodobna družba in bo svojo pozornost pri pripravi pouka, gradiv, pri načrtovanju in pri izvedbi učne ure vseskozi usmerjal/a na učenca in na njegove potrebe, želje, interese,... in pripravil/a sodoben, inovativen in zanimiv pouk. Institucije morajo pri temu podpirati učitelje/ice tako, da prisluhnejo potrebam učiteljev/ic, učencev/k in okolja. Motivacija, samospoštovanje in vzajemna pomoč, ki prispevajo $\mathrm{k}$ strokovni in osebnostni rasti učitelja/ice, bistveno vplivajo tudi na vsakodnevno pedagoško prakso, na uresničevanje učitelja/ice in na udejanjanje sprememb $\mathrm{v}$ šolah in posledično tudi $\mathrm{v}$ družbi.

\section{Vloga univerze}

Univerza ima v našem okolju nalogo in dolžnost, da zagotavlja ustrezno izobraževanje bodočih učiteljev/ic, a tudi drugih zaposlenih na področju poučevanja, promocije in zaščite manjšinskega jezika, da poskrbi za vseživljenjsko izobraževanje zaposlenih na omenjenem področju, da krepi sodelovanje ne le med šolami s slovenskim in $\mathrm{z}$ italijanskim učnim jezikom v Sloveniji in Italiji, temveč tudi med drugimi institucijami, ki delujejo na področju poučevanja, zaščite in promocije manjšinskega jezika, in sicer na nacionalni, čezmejni, pa tudi na mednarodni ravni. Poleg tega je ključnega pomena, da spodbuja raziskovanje, ki odpira in odkriva nove, inovativne poti in strategije za učenje in poučevanje, zaščito ter promocijo jezikov v večjezičnem okolju. ${ }^{22}$

Glej Lucija Čok in Ana Beguš, ur., Prerez jezikovne politike Univerze na Primorskem (Koper: UP, 201 I ); Monika Kalin Golob, Marko Stabej, Mojca Stritar, Gaja Cerv, Primerjalna studija o ućnem jeziku v visokem šolstvu v Republiki Sloveniji in izbranih evropskih državah (Ljubljana: Ministrstvo za izobraževanje, znanost, kulturo in šport, 20I2); Zudič Antonič, »Vzgoja za dvojezičnost in večjezičnost;« Zudič Antonič in Zorman, »Izobraževanje učiteljev in medkulturna vzgoja.
Oddelek za italijanistiko Fakultete za humanistične študije Univerze na Primorskem zgornje cilje uresničuje preko:

- $\quad$ študijskih programov in prenovljenih učnih načrtov,

- raziskav v okviru projektov,

- organizacije simpozijev, izobraževanj, predavanj, okroglih miz, delavnic, srečanj, prireditev,...

- udeležbe na simpozijih, izobraževanjih, predavanjih, okroglih mizah, delavnicah, srečanjih, prireditvah,...

- mobilnosti osebja in študentov/k,

- povezovanja z okoljem.

Oddelek za italijanistiko se od začetka svojega delovanja trudi pripravljati študijske programe v skladu s potrebami sodobnega izobraževanja, na področjih svojega delovanja (v skladu z novimi spoznanji stroke), prenavlja učne načrte in v vsakodnevno pedagoško prakso vnaša novosti in spremembe, uporablja sodobna didaktična gradiva ter sodeluje s šolami, kjer se italijanski jezik uči in poučuje kot $\mathrm{J}_{1}, \mathrm{~J} 2, \mathrm{TJ}{ }^{23}$ Sodeluje $\mathrm{z}$ okoljem in $\mathrm{z}$ institucijami v Sloveniji, Italiji, pa tudi širše, ki se ukvarjajo $z$ učenjem in poučevanjem, z zaščito in s promocijo italijanskega jezika. Osredotoča se na raziskave, kjer je pouk osredinjen na učenca in organizira usposabljanja, osredinjena na učitelja. Izsledke, rezultate in didaktična gradiva preko različnih oblik izobraževanj širi med študente, učitelje, učence.

Izobraževanja učiteljev se je Oddelek za italijanistiko lotil na dveh ravneh: na regionalni/ nacionalni ravni z organizacijo različnih oblik izobraževanja in usposabljanja (pogosto na teme, ki so jih predlagali učitelji/ice) in na ravni neposrednega dela $\mathrm{z}$ učitelji (v obliki nastopnih predavanj, predstavitev novih gradiv in uvajanja novih

23 GlejZudič Antonič in Malčič, »Bisogni emersi; « Nives Zudič Antonič, »L'educazione letteraria in prospettiva interculturale, «v Studi interculturali : interferenze linguistiche, didattiche e culturali nel territorio istroquarnerino, ur. Rita Scotti Jurić e Tarita Štokovac (Pola: Univerza Juraj Dobrila, Oddelek za italijanski jezik, 20ı ıb); Zudič Antonič in Zorman, »Izobraževanje učiteljev in medkulturna vzgoja; « Zorman in Zudič Antonič, »Pojmovanje medkulturne vzgoje med učitelji in njihova medkulturna občutljivost.« 
praks, preko refleksije pred in po izvedenih učnih urah in preko svetovalnega dela).

Izobraževanj se udeležujejo učitelji/ice, ki so zaposleni na šolah s slovenskim in $\mathrm{z}$ italijanskim učnim jezikom, kjer se poučuje italijanski jezik kot Ji, J2 ali TJ, pa tudi zaposleni na Oddelku. ${ }^{24}$ Pri komunikaciji uporabljamo slovenski in italijanski jezik, si izmenjujemo informacije, izkušnje, primere dobrih praks, spoznavamo težave, probleme in si zastavljamo nove cilje ter iščemo rešitve. Ta oblika sodelovanja učiteljem/ icam Oddelka za italijanistiko omogoča permanentno izobraževanje $\mathrm{v}$ stroki, poleg tega pa omogoča stik $\mathrm{z}$ učitelji/cami šol s slovenskim in z italijanskim učnim jezikom vseh stopenj, komunikacijo v slovenskem in italijanskem jeziku, vpogled v realno situacijo ...

Oddelek za italijanistiko spremlja in spodbuja učitelje/ice pri usposabljanjih, motivira pa tudi študente/ke, ki se redno udeležujejo različnih oblik izobraževanja na različne teme. $\mathrm{V}$ letih delovanja smo uspeli vzpostaviti mrežo šol s slovenskim in italijanskim učnim jezikom (ne le na območju Slovenske Istre, ampak celotne Slovenije, pa tudi iz drugih dvojezičnih območij, v drugih državah (Italija, Avstrija, Madžarska, Velika Britanija) ter $\mathrm{z}$ institucijami, ki se ukvarjajo z vprašanji ohranjanja, zaščite in promocije manjšinskih jezikov. ${ }^{25} \mathrm{~V}$ prihodnje bi bilo smiselno sodelovanje še okrepiti in ga razširiti na druga območja.

\section{Raziskave v okviru projektov}

Raziskave, katere smo v zadnjih letih izvedli na področju poučevanja in učenja italijanskega jezika kot manjšinskega jezika, so izhajale iz potreb okolja in so bile usmerjene $\mathrm{v}$ ugotavljanje dejanskega stanja v šolah, v odkrivanje težav, potreb in izzivov, na katere so nas opozarjali vodilni delavci/ke, učitelji/ce, učenci/ke in starši. $\mathrm{Na}$ podlagi ugotovljenega stanja smo skušali poiska-

24 Zudič Antonič in Zorman, »Izobraževanje učiteljev in medkulturna vzgoja.«

25 Glej Norina Bogatec in Nives Zudič Antonič, ur., Vzgajati k razlićnosti:predhodna poročila interdisciplinarne primerjalne raziskave med Italijo in Slovenijo (Trst: Slovenski raziskovalni inštitut SLORI; Koper: Univerza na Primorskem, Fakulteta za humanistične študije, 2015). ti ustrezne rešitve, organizirati permanentno izobraževanje učiteljev/ic ter ponuditi sodobna in ustrezna didaktična gradiva, ki bi služila kot zgled za delo v razredu. ${ }^{26}$

V okviru nacionalnih, čezmejnih in mednarodnih projektov, $\mathrm{v}$ katerih smo sodelovali, smo tako raziskovali:

- pomen večjezičnosti in razvijanja medkulturne sporazumevalne zmožnosti,

- $\quad$ strategije za vzgajanje k različnosti,

- iskanje inovativnih in ustvarjalnih pristopov v vzgoji in izobraževanju,

- $\quad$ strategije za promocijo manjšinskih jezikov $\mathrm{v}$ večjezičnem okolju,

iskanje modela za usposabljanje učiteljev v večjezičnih okoljih.

\section{Predstavitev dveh mednarodnih projektov}

\section{Comenius 2.I}

Za začetek predstavljamo dva mednarodna projekta Comenius 2.I: Promocija manjšinskih jezikov v večjezičnih območjih s poudarkom na izobraževanju učiteljev in učiteljic (2003-2006) ter projekt Info - opredelitev modela za usposabljanje učiteljev v večjezičnih okoljih (2004-2007).

$\mathrm{V}$ prvem projektu so sodelovali partnerji iz različnih dvojezičnih območij v Avstriji, Italiji, na Madžarskem in v Sloveniji in se je osredotočal na zgodnje učenje in poučevanje manjšinskih jezikov (za otroke 6-Io let) in na analizo dobrih praks. Temeljni cilj projekta je bila prepoznava možnosti za izboljšavo didaktičnih strategij, pristopov $\mathrm{k}$ učenju in poučevanju manjšinskega jezika ter priprava ustreznih gradiv za dvojezičen pouk na zgodnji stopnji šolanja. ${ }^{28}$

Drugi projekt, v katerem so sodelovali partnerji iz različnih dvojezičnih območij v Avstriji, Italiji, Veliki Britaniji in v Sloveniji, si je za temeljni cilj zadal opredelitev modela za izobra-

\footnotetext{
26 Zudič Antonič in Malčič, »Bisogni emersi.«

27 Nosilka obeh projektov je Nives Zudič Antonič.

28 GlejJosefHieden in Karl Heinz Ieden, ur., Expertisen, Förderung von Minderheitensprachen im mehrsprachigen Raum in der Lehrerbildung, Bd. I (Klagenfurt: Pädagogische Akademie des Bundes in Kärnten, 2005).
} 
ževanja učiteljev, ki poučujejo v večjezičnih okoljih in o katerem bo tekla beseda $\mathrm{v}$ nadaljevanju. ${ }^{29}$

V okviru obeh projektov smo izdali dve interaktivni didaktični gradivi za zgodnje poučevanje italijanskega jezika kot manjšinskega jezika. Prvo gradivo, Citronček in Giovanin/Giovanin e la farfalla je dvojezično (v slovenščini in v italijanščini), avtor zgodbe je Vanja Pegan, pisatelj iz Pirana, ilustracije pa so delo akademske slikarke iz Pirana, Fulvie Zudič. ${ }^{3}$

Drugo gradivo, Arabella, je večjezično (v italijanščini, slovenščini, nemščini in dveh različicah ladinščine), avtorji zgodbe so otroci osnovne šole $z$ italijanskim učnim jezikom iz Pirana, ilustracije pa so delo akademske slikarke iz Pirana, Fulvie Zudič. ${ }^{31}$

Cilji obeh didaktičnih gradiv so učenje in poučevanje manjšinskega in večinskega jezika, razvijanje bralne kulture, vzgoja za večjezičnost in za različnost, promocija jezikov in kulturne dediščine. Zgodbi govorita o otrokovem vsakda$\mathrm{nu}$ in sta v skladu s starostjo, interesi, okoljem, ki pa je $\mathrm{v}$ marsičem podobno okolju in vsakdanu otrok, ki živijo v drugih, drugačnih okoljih; izhaja iz potreb otrok in jim želi približati književno besedilo. Besedilo, ilustracije in dejavnosti spodbujajo branje, motivacijo za branje in bralno kulturo, hkrati pa razvijajo medkulturno vzgojo. Ob branju zgodbe, ki izhaja iz otrokovega sveta in njegovega doživljanja le-tega, se otrok uči jezik, hkrati pa razmišlja o dogodkih v svojem vsakdanu, pogovarja se $\mathrm{z}$ drugimi, išče podobnosti in razlike, ozavešča določene vrednote in pomen znanja jezikov. ${ }^{32}$ Didaktično gradivo je privlačno na pogled, ilustracije spodbujajo otro-

29 Olimpia Rasom, ur. Info project: designing a training model for teachers working in multilingual areas with minority language. Part $\mathrm{I}$, The research and the European training model (Bolzano: Istitut Pedagogich Ladin, 2007).

30 Vanja Pegan, Nives Zudič Antonič in Anja Zorman, Citronček in Giovanin = Giovanin e la farfalla $($ Koper: UP PeF, 2006).

31 Metka Malčič, Sonia Mugherli Imperl, Vesna Vojvoda, Meri Ščulac, Nives Zudič Antonič, Arabella (Koper: Fakulteta za humanistične študije, 2007).

32 Nives Zudič Antonič, »Za različno vizijo in zaznavo sveta: jeziki, kulture in medkulturnost, « Šolsko polje, letn. 19, št. 3/4, (2008). kovo domišljijo, obenem pa mu nudijo užitek in sprostitev.

Gradivo spodbuja kritično mišljenje; besedilo in dejavnosti spodbujajo $\mathrm{k}$ izmenjavi mnenj, izkušenj med sošolci, vrstniki iz drugih šol, držav, z odraslimi,... Na ta način prispevajo $\mathrm{k}$ ustvarjalnemu učenju, otrokom pa omogočajo tudi možnost izbire (med individualnim delom, delom v dvojicah, v skupinah). Tudi dodatna gradiva, ki so na voljo, zagotavljajo možnost izbire in nadgradnje glede na posameznikovo znanje, potrebe, interese.

Otroci so gradivo sprejeli $\mathrm{z}$ navdušenjem, predvsem so pohvalili zgodbi, s katerima so se lahko poistovetili, všeč jim je bilo, da so bili aktivni in da so na njim prijeten način spoznavali sebe in druge. Pritegnilo jih je tudi delo z računalnikom. Izrazili so željo, da bi tudi v prihodnje imeli možnost delati s tovrstnim gradivom, ki ga lahko uporabljajo tudi na domačem računalniku. Opazili smo tudi, da so sami brali besedili v obeh jezikih ( $\mathrm{v}$ prvem primeru) oziroma $\mathrm{v}$ več jezikih (v drugem primeru), primerjali besedišče in se spraševali, za katere jezike gre, kje jih govorijo itd.

\section{Evropski model za usposabljanje učiteljev/ic, ki poučujejo v večjezičnih območjih}

$\mathrm{V}$ nadaljevanju izpostavljamo izsledke raziskave, ki smo jo izvedli v okviru mednarodnega projekta Info in predstavlja evropski model za usposabljanje učiteljev/ic, ki poučujejo v večjezičnih območjih. Ciljni jeziki projekta so bili slovenščina, italijanščina, nemščina, furlanščina, valižanščina, ladinščina, sardščina.

$\mathrm{Na}$ podlagi intervjujev in vprašalnikov, ki so jih izpolnili učitelji/ce, ravnatelji/ce, starši in svetovalci/ke iz različnih evropskih večjezičnih področjih, so sodelujoči/e v projektu opredelili/e elemente, ki naj bi jih vseboval Evropski model za usposabljanje učiteljev/ic, ki poučujejo v večjezičnih območjih. Skupina Info je na podlagi ugotovitev in dognanj pripravila, organizirala in ob pomoči povabljenih predavateljev izvedla izobraževanje, ki so se ga udeležili/e učitelji/ ce iz različnih evropskih dežel. Po končanem iz- 
obraževanju je delovna skupina Info analizirala komentarje udeležencev/k (intervjuji, vprašalniki). Udeleženci/ke so po izobraževanju v svojem okolju (in izhajajoč iz potreb učencev/ $\mathrm{k}$ in usvojenega znanja na izobraževanju ter $\mathrm{v}$ sodelovanju $\mathrm{z}$ mentorji/cami) izdelali/e in $\mathrm{v}$ razredu preizkusili učne materiale za sodobno poučevanje v manjšinskih jezikih/manjšinske jezike. Le-te so predstavili/e na dvodnevnem srečanju učiteljem/icam, ki so sodelovali/e pri izobraževanju in predstavnikom delovne skupine Info. ${ }^{33}$

Učitelji/ce, ki so sodelovali/e v raziskavi, so izpostavili/e sledeče potrebe učiteljev/ic, ki poučujejo manjšinske jezike:

- vpetost in sodelovanje okolja,

- uporaba manjšinskega jezika v vseh dejavnostih,

- promoviranje timskega dela,

- izmenjave med strokovnjaki, učenci, šolami,

- promoviranje rabe učnih tehnologij,

- ustrezna finančna podpora.

Učitelji/ce so izpostavili/e tudi pomen kontinuiranosti in vztrajnosti pri različnih dejavnostih v manjšinskem jeziku, skrb za jezik in za pravilno izražanje v manjšinskem jeziku. Poleg tega je bil izpostavljen problem ustrezno izobraženega kadra, ki pozna okolje in njegove specifike in je z njim povezan. Zelo pomemben dejavnik pa so tudi kvalitetna in ustrezna didaktična gradiva, ki naj bi bila ustrezno dokumentirana in lahko dostopna, predvsem pa sodobna.

Učitelji/ice menijo, da bi že upoštevanje vseh naštetih elementov imelo pozitiven vpliv na sprejemanje posameznega manjšinskega jezi$\mathrm{ka}$ in na upoštevanje in spoštovanje različnosti. ${ }^{34}$

\footnotetext{
33 Rasom, Infoproject.

34 Nives Zudič Antonič in Metka Malčič, » Bisogni emersi.«
}

Čezmejni projekt Interreg Slovenija/Italija: EDUKA Vzgajati k različnosti/Educare alla diversità (20II-20IS) $)^{35}$

Temeljni cilj projekta je bila promocija medkulturnih vrednot kot temeljev oblikovanja in razvijanja odnosov $\mathrm{v}$ večetnični in večjezikovni družbi. Za dosego tega cilja smo želeli ustvariti znanje in orodja (didaktično in informativno gradivo, priročnike, publikacije, igre ...) za vzgajanje $\mathrm{k}$ različnosti in medkulturnosti ter jih posredovati šolajoči mladini in učnemu kadru na vseh stopnjah izobraževanja. V ta namen so delovale mreže čezmejnega sodelovanja med šolami na vseh ravneh, med raziskovalnimi ustanovami in univerzami, med javnimi upravami in ustanovami, ki delujejo na področju medkulturne vzgoje, ter med organizacijami znotraj tradicionalnih in novih etničnih manjšin. Te so izvajale izobraževalne, informativne, promocijske in raziskovalne aktivnosti. ${ }^{36}$

$\mathrm{V}$ nadaljevanju predstavljamo dvojezično (v slovenščini in v italijanščini) didaktično igro Igra burje/Il gioco della Bora, ki je namenjena otrokom petega razreda osnovne šole. $\mathrm{V}$ elektronski obliki je dostopna na spletni strani projekta http://www.eduka-itaslo.eu/. Njeni cilji so sledeči:

učiti se materni/drugi/tuji jezik, spoznavati in odkrivati sebe in druge, svoje ožje in širše okolje,

- razmišljati, se poslušati, sodelovati, si pomagati in na podlagi starih in novih izkušenj uzaveščati podobnosti in razlike ter preko igre na prijeten in zabaven način, usvajati medkulturno sporazumevalno zmožnost.

Igra je nastala v okviru delovne skupine, v kateri so sodelovale učiteljice iz osnovnih šol iz Slovenije in Italije, iz šol $z$ italijanskim in slovenskim učnim jezikom, z obeh strani meja, pod mentorstvom ene izmed avtoric pričujočega prispevka. Delovno skupino je vodila misel, da bi na otrokom zanimiv, privlačen in primeren na-

35 Nosilka projekta je Nives Zudič Antonič. Dostopno na: http:// eduka-itaslo.eu/pagina.php?p=projekt\&lang=slo.

36 Bogatec in Zudič Antonič, Vzgajatik razlićnosti. 
čin približali teme čezmejnih in stičnih prostorov in jih popeljali v svet odkrivanja posebnosti in lepot okolja, v katerem živijo. Pri pripravi igre, pri izbiri tem in vprašanj, pa tudi pri oblikovanju vrste in oblike igre, smo sledile temeljnim ciljem projekta. Na začetku smo se posvetile predvsem iskanju podobnosti in skupnih elementov čezmejnega prostora, ki se jih mnogokrat niti ne zavedamo, saj so del našega vsakdana, o katerem le redko razmišljamo. Igra je zasnovana kot potovanje, kot izlet z ladjo po Tržaškem zalivu, kjer nas burja premetava »sem ter tja «, iz slovenske na italijansko stran čezmejnega območja. Na postankih morajo igralci odgovarjati na vprašanja o jezikih in narečjih, o značilnostih in posebnostih okolja, o navadah in običajih, o tradicijah ... Igra je zastavljena kot življenje: omogoča, da se otroci učijo in utrjujejo znanje, da poslušajo drug drugega, se spoznavajo, med seboj sodelujejo in si pomagajo ... V igro smo vključili dva skupna naravna elementa, morje in burjo, značilna za naše območje, ki nas v marsičem določata in vplivata na življenje, običaje in navade. Zdela sta se nam še posebej pomenljiva prav za razvijanje medkulturne sporazumevalne zmožnosti, saj sta to dva elementa, ki ne poznata meja.

$\mathrm{Na}$ tem mestu bi izpostavili pomen, ki ga je imelo za strokovno in osebnostno rast učiteljev/ ic sodelovanje in delo v skupini. Znotraj skupine smo skušale doseči cilje, ki smo jih zastavile tudi pri didaktični igri. $\mathrm{Na}$ delovnih srečanjih smo uporabljale oba jezika, slovenskega in italijanskega, izmenjavale smo si znanje, stališča, izkušnje, vrednote, se medsebojno spoznavale, spoznavale oba šolska sistema, prednosti in slabosti, primerjale jezike, narečja, se pogovarjale o navadah, običajih, tradiciji ... Gradile smo na odprtem in poglobljenem dialogu, zato so naša srečanja predstavljala dragoceno izkušnjo, ki nas je vsestransko obogatila. ${ }^{3}$

37 Metka Malčič, »Educare alla diversità attraverso il gioco: predavanje na konferenci, « A ATI International Conference Abroad (Napoli: Università degli Studi di Napoli »L'Orientale« e Università degli Studi di Napoli $»$ Federico II $\ll, 2016)$.

38 Malčič, Metka »Educare alla diversità attraverso il gioco: predavanje na konferenci.«

\section{Projekt Labicum: Jeziki kot most} za medkulturno sporazumevanje in razumevanje

V okviru ARRS projekta Labicum: Jeziki kot most za medkulturno sporazumevanje in razumevanje (2004-2007) je Univerza na Primorskem sodelovala z Britanskim svetom Slovenije. Raziskovalci/-ke, vključeni/-e v projekt, smo imeli/e več izobraževanj mednarodno priznanih strokovnjakov s področja razvijanja medkulturne sporazumevalne zmožnosti in državljanske vzgoje. Poleg tega smo na študijskem obisku v tujini obiskali/e univerzo v Durhamu, Strasbourgu in Benetkah, kjer smo imeli/e organizirana izobraževanja, delavnice in oglede univerzitetnih jezikovnih centrov. Usposabljali/-e smo se za delo v razredu in pripravljali/-e didaktično gradivo za poučevanje jezika in razvijanje medkulturne sporazumevalne zmožnosti na univerzitetnem nivoju.

Za poučevanje italijanskega jezika na univerzitetnem nivoju smo izdali/e učbenik za poučevanje italijanskega jezika in razvijanje medkulturne sporazumevalne zmožnosti Il vicino diverso, Bližina drugosti. Učne enote obravnavajo večno aktualne teme, ki so posebnega pomena tudi za stične prostore. Raznolika avtentična gradiva (avdio in video posnetki, članki iz časopisov in revij, odlomki iz romanov, poezija ...) osvetljujejo večne dileme človeštva iz več zornih kotov in že sama po sebi spodbujajo diskusijo in kritično razmišljanje. Vaje vodijo študenta skozi slušno in bralno razumevanje (za opazovanje novega kulturnega okolja), ustno sporočanje (za izmenjavo mnenj, razlag, zamisli ...), utrjevanje in širjenje besedja (za lažje razumevanje) in pisno sporočanje (pri učnih enotah z lažjimi besedili). Delo v dvojicah in manjših skupinah spodbuja komunikacijo, študenti odgovarjajo na vprašanja, ki imajo (v določenih primerih) lahko različne odgovore, primerjajo različne poglede, posredujejo doživetja, lastne izkušnje, si izmenjujejo informacije in tako skupaj rešujejo probleme. S samostojnim delom (predvsem za iskanje novih informacij) razvijajo samostojnost pri iskanju informacij in odgovornost $\mathrm{v}$ odnosu do lastnega izobraževanja. 
Cilj učnih enot je pridobivati si jezikovno znanje, spoznavati in uzaveščati podobnosti in razlike med kulturami, pridobivati si nova znanja, razvijati spretnosti in kompetence, ki bodo služile pri medkulturnem sporazumevanju. Zastavljene so tako, da ponujajo študentom/ kam možnost diferenciranega in samostojnega dela. $\mathrm{Na}$ koncu vsake učne enote je vprašalnik, kjer si študent/ka vzame čas za razmislek in odgovori na vprašanja o lastnem razvijanju medkulturne sporazumevalne zmožnosti. $\mathrm{Na}$ ta način spremlja lastno učno pot, se vse bolj zaveda svojih prednosti in pomanjkljivosti ter tako postaja protagonist/ka svojega učenja in svoje osebnostne rasti.

Študentje/ke so pohvalili gradivo, saj so se prvič srečali s tovrstnimi gradivi, všeč jim je bilo, da so bile določene teme, ki so še vedno prevečkrat tabu teme, o katerih se skoraj nihče ne želi pogovarjati, predstavljene iz različnih zornih kotov in $\mathrm{z}$ uporabo video posnetkov in odlomkov iz slovenskih in italijanskih filmov. Po njihovem mnenju naj bi jim obravnavane vsebine koristile ne le pri študiju, ampak tudi pri vsakdanjem življenju in delu.

\section{Sklepne misli}

Zdi se, da je poučevanje in učenje manjšinskih jezikov, kljub prizadevanjem Evropske skupnosti in posameznih držav članic, $v$ današnji družbi mnogokrat postavljeno na stranski tir, saj se učenci velikokrat raje učijo druge tuje jezike kot manjšinske. Oddelek za italijanistiko Fakultete za humanistične študije Univerze na Primorskem Koper želi s sodobnimi študijskimi programi, z vsakodnevnim pedagoškim delom, osredinjenem na učenca, z izobraževanji za učitelje/ice in študente/ke ter s sodelovanjem v nacionalnih, čezmejnih in mednarodnih projektih, zagotavljati znanje, spodbujati in motivirati vse vpletene v vzgojo in izobraževanje ter dokazovati, da lahko z novimi, sodobnimi, učencu prijaznimi gradivi, metodami in strategijami, omogočimo drugačno učenje in tako promoviramo učenje manjšinskih jezikov.
V prihodnosti bi morali še okrepiti različne oblike sodelovanja in poskusiti vključiti $\mathrm{v}$ raziskave šole, učitelje/ice in učence/ke ter institucije, s katerimi še nismo imeli priložnosti sodelovati in poskušati najti in razviti nove poti za povezovanje in širjenje znanja. Področji, ki bi ju veljalo v prihodnosti razvijati, sta predvsem poučevanje nejezikovnih predmetov v tujem jeziku (CLIL) in računalniško podprto učenje jezikov (CALL).

\section{Povzetek}

Na narodnostno mešanem območju Slovenske Istre je učenje/poučevanje italijanskegajezika kot manjšinskega jezika posebej občutljiva tema, ki se jo je potrebno lotevati z veliko mero odgovornosti in sistematičnosti. Univerza ima v tem okolju nalogo in dolžnost, da zagotavlja ustrezno izobraževanje bodočih učiteljev/učiteljic, da poskrbi za vseživljenjsko izobraževanje že zaposlenih učiteljev/učiteljic, da krepi sodelovanje ne le med šolami s slovenskim in z italijanskim učnim jezikom v Sloveniji in Italiji, temveč tudi med drugimi inštitucijami, ki delujejo na področju poučevanja, zaščite in promocije manjšinskega jezika. Ključnega pomena je izhajati izpotreb, ki se pokažejo v okolju, odreagirati in skušati iskati rešitve ter nove, drugačne poti. $\mathrm{V}$ prispevku se bomo osredotočili na izsledke nekaterih raziskav in predstavili nekaj predlogov za izboljšanje dela v razredu, preko katerih bi na vseh stopnjah izobraževanja uresničevali model, ki že obstaja. V okviru nacionalnih, čezmejnih in mednarodnih projektov, $\mathrm{v}$ katerih smo sodelovali, smo raziskovali: pomen večjezičnosti, razvijanje medkulturne kompetence, strategije za promocijo manjšinskih jezikov v večjezičnem okolju, iskanje inovativnih in ustvarjalnih pristopov v vzgoji in izobraževanju, iskanje modela za usposabljanje učiteljev v večjezičnih okoljih ter strategije za vzgajanje k različnosti. Izsledke raziskav in predloge za delo v vsakodnevni pedagoški praksi smo preko simpozijev, seminarjev, delavnic in neformalnih srečanj predstavili pedagoškim delavcem/kam, študentom $/ \mathrm{kam}$, učencem $/ \mathrm{kam}$.

Ključne besede: poučevanje/učenje italijanskega jezika, manjšinski jezik, raziskave, večjezičnost, različnost 


\section{Summary}

The purpose of this paper is to present some results of the research in the field of learning and teaching of the Italian language as a minority language and to encourage new initiatives and research that will connect even more schools and institutions. The presented studies were conducted in collaboration with selected schools at all levels, in which the teaching of the Italian language as a mother tongue, the second language and a foreign language and selected institutions dealing with promotion and protection of the Italian language as a minority language (national, cross border and international level).

In the article some fundamental theoretical principles of modern language learning and teaching are presented, followed by the description of the characteristics of modern training for teachers and the role it plays in the process of ensuring an appropriate study, teacher training and protection of the Italian language as a minority language University of Primorska and the Italian Department of Faculty of Humanities. At the and some of the projects are presented together with the main goals and findings.

Key words: teaching/learning Italian language, minority language, researches, multilingualism, diversity

\section{Literatura in viri}

Armellini, Guido. Come e perché insegnare letteratura. Strategie e tattiche per la scuola secondaria. Bologna: Zanichelli, 1987.

Balboni, Paolo E. Tecniche didattiche per l'educazione linguistica. Torino: UTET, 1998.

Balboni, Paolo E. Educazione bilingue. Perugia: Guerra, 1999.

Baloh, Barbara. »Slovenščina kot drugi jezik v šolah z italijanskim učnim jezikom v Slovenski Istri.« V Slovenšcina in njeni uporabniki $v$ luči evropske integracije, ur. Vesna Mikolič in Karin Marc Bratina, I3I-I 47, 295-296. Koper: Univerza na Primorskem, Znanstveno-raziskovalno središče, Založba Annales, 2005.

Baker, Colin. Attitudes and Language. Clevedon: Multilingual Matters, 1992.
Bela knjiga o medkulturnem dialogu. Strasbourg: Svet Evrope, 2008.

Bennett, Janet M. et. al. "Developing intercultural competence in the language classroom." $\mathrm{V}$ Culture as the Core: Integrating Culture into the Language Classroom, ur. R. Michael Paige in Dale L. Lange, 237-270. Minneapolis: University of Minnesota, 1999.

Bogatec, Norina in Nives Zudič Antonič, ur. Vzgajati $k$ različnosti: predhodna poročila interdisciplinarne primerjalne raziskave med Italijo in Slovenijo. Trst: Slovenski raziskovalni inštitut SLORI; Koper: Univerza na Primorskem, Fakulteta za humanistične študije, 2015. Http://eduka-itaslo.eu/ uploads/analize_slo/uploadsanalize_sloz6. pdf\#SLOED_low.pdf.

Byram, Michael. Cultural Studies and Foreign Language Education. Clevedon: Multilingual Matters, 1989.

Byram, Michael. Teaching and Assessing Intercultural Communicative Competence. Clevedon: Multilingual Matters, 1997.

Byram, Michael in Geneviève Zarate. Définitiones, objectifs et évaluation de la compétence socio-culturale. Strasbourg: Report fort he Coucil of Europe, 1994.

Cesari Lusso, Vittoria. "La dimensione interculturale nell'educazione: riflessioni e riferimenti per l'azione pedagogica." V L'educazione interculturale, ur. Fulvio Poletti, 87II . Firenze: La Nuova Italia, 1992.

Ciliberti, Anna. "Language Ideologies and the Current State of Language Teaching in Italy." V Fuzzy Boundaries? Reflection on Modern Languages and the Humanities, ur. R. Di Napoli, L. Polezzi, A. King, 95-Io9. London: CILT Pubblications, $200 \mathrm{I}$.

Ciliberti, Anna. Glottodidattica: per una cultura dell'insegnamento linguistico. Roma: Carocci, 2012.

Council of Europe, Common European Framework of Reference for Languages: Learning, Teaching, Assessment (Cambridge: University Press, 200I). 
Cummins, Jim. Language, Power and Pedagogy. Bilingual Children in the Crossfire. Clevedon: Multilingual Matters, 200I.

Čebron, Neva. »Medkulturno sporazumevanje kot kritičen pogled na lastno kulturno identiteto.«V Brez spopada: kultur, spolov, generacij, ur. Veronika Tašner et al., 19-28. Ljubljana: Pedagoška fakulteta, 2009.

Čebron, Neva. »An Investigation into Intercultural Communication Issues in High School Curricula in Italy, Slovenia and Turkey.« Journal of foreign language teaching and applied linguistics (2014): 149189. Http://j-ftal.org/storage/j-fltal-I5.pdf.

Čok, Lucija, ur. Blizina drugosti $=$ The close otherness. Koper: Univerza na Primorskem, Znanstveno-raziskovalno središče, Založba Annales, 2006.

Čok, Lucija, ur. Izobraževanje za dvojezičnost v kontekstu europskih integracijkih procesov: učinkovitost dvojezičnih modelov izobraževanja $v$ etnično mešanih okoljih Slovenije. Koper: Annales, 2009.

Čok, Lucija in Ana Beguš, ur. Prerez jezikovne politike Univerze na Primorskem. Koper: UP, 20II). Http://www.upr.si/index.php?page $=$ static \&item $=82$.

Dabène, Louise, et al. Variations et rituels en classe de langue. Paris: Hatier-Crédif, 1990.

Dell'Aquila, Vittorio in Gabriele Iannaccaro. La pianificazione linguistica. Roma: Carrocci, 2004 .

Demetrio, Duccio in Graziella Favaro. Didattica interculturale. Nuovi sguardi, competen$z e$, percorsi. Milano: Franco Angeli, 2002.

Evropske listine o regionalnih in manjsinskih jezikih, ETS št. I48. Strasbourg: Svet Evrope 1992. Dostopno na spletni strani: http:// www.svetevrope.si/sl/dokumenti_in_publikacije/konvencije/I48/

Fabbro, Franco. Il cervello bilingue. Neurolinguistica e poliglossia. Roma: Astrolabio Ubaldini, 1996.

Francescato, Giuseppe. Il bilingue isolato. Studi sul bilinguismo infantile. Bergamo: Minerva Italica, 198I.
Gardner, Robert C. Social psychology and second language learning. The role of attitudes and motivation. London: Edward Arnold, 1985.

Grosjean, François. Studying Bilinguals. Oxford: University Press, 2008.

Hieden, Josef in Karl Heinz Ieden, ur. Expertisen, Förderung von Minderheitensprachen im mehrsprachigen Raum in der Lehrerbildung, Bd. I. Klagenfurt: Pädagogische Akademie des Bundes in Kärnten, 2005.

Kalin Golob, Monika, Marko Stabej, Mojca Stritar in Gaja Červ. Primerjalna studija o učnem jeziku v visokem šolstvu v Republiki Sloveniji in izbranih europskih državah. Ljubljana: Ministrstvo za izobraževanje, znanost, kulturo in šport, 2012.

Kramsch, Claire. Context and Culture in Language Teaching. Oxford: Oxford University Press, 1993.

Lafayette, Robert C. "Integrating the Teaching of Culture into the Foreign Language Classroom. V Toward a New Integration of Language and Culture, ur. A.J. Singerman, 47-62. Middlebury: VT, The North-east Conference, 1997.

Lange, Dale L. »Implications of theory and research fort he development of principles for teaching and learning culture in second language classrooms. $\ll \mathrm{V}$ Culture as the Core: Perspectives in Second Language Education, ur. Dale L. Lange in R. Michael Paige, 271-336. Greenwich: IAP, 2003.

Malčič, Metka. »Educare alla diversità attraverso il gioco: predavanje na konferenci.« AATI International Conference Abroad. Napoli: Università degli Studi di Napoli »L'Orientale« e Università degli Studi di Napoli $\gg$ Federico II «, 2016.

Malčič, Metka, Sonia Mugherli Imperl, Vesna Vojvoda, Meri Ščulac in Nives Zudič Antonič. Arabella. Koper: Fakulteta za humanistične študije, 2007.

Mikolič, Vesna. "Slovene and Italian Languages in Contact in the Ethnically Mixed Area of Slovene Istria." Annales, Serie Storia e Sociologia, št. I2/2, (2002): 42I-436. 
Mikolič, Vesna, Susanna Pertot in Nives Zudič Antonič. Med kulturami in jeziki = Tralingue e culture. Koper: Univerza na Primorskem, Znanstveno-raziskovalno središče, Založba Annales, 2006.

Nalesso, Marilena in Metka Malčič. "La pratica didattica." V Progetto Info: Il corso di formazione e la pratica didattica, ur. Olimpia Rasom, 20-25. Bolzano: Istitut Pedagogich Ladin, 2007.

Nećak Lük, Albina. »Jezikovni pouk v dvojezični šoli: predstavitev učinkov inovacije.« V Uciti drugi/tuji jezik: kje, koga, kako= Teaching second/foreign languages: where, to whom, how = Enseigner les languages secondes/étrangères: où, à qui, comment (Tempus Joint European Project 3767), ur. Lucija Čok, I3I-I 46. Ljubljana: Pedagoška fakulteta, 1994.

Novak-Lukanovič, Sonja. »Dvojezična vzgoja in izobraževanje: vloga $\mathrm{v}$ družbi in stališča posameznikov: (prikaz rezultatov raziskave), « Razprave in gradivo, 28 (1993): 38-45.

Novak-Lukanovič, Sonja, Nives Zudič Antonič in Štefan Varga. »Vzgoja in izobraževanje na narodno mešanih območjih v Sloveniji.« V Bela knjiga o vzgoji in izobraževanju v Republiki Sloveniji, ur. Janez Krek in Mira Metljak, 347-367. Ljubljana: Zavod RS za šolstvo, $201 \mathrm{I}$.

Okvirne konvencije SE o varstvu narodnih manjsin. Strasbourg: Svet Evrope, 1995. Dostopno na spletni strani: Http://www.svetevrope.si/sl/dokumenti_in_publikacije/ konvencije/157/.

Pegan, Vanja, Fulvia Zudič, Nives Zudič Antonič in Anja Zorman. Citronček in Giovanin $=$ Giovanin e la farfalla. Koper: Univerza na Primorskem, Pedagoška fakulteta, 2006.

Pertot, Susanna. Dvojezični otrok: priročnik za starše = Il bambino bilingue: manualetto per i genitori. Trst: Slovenski raziskovalni inštitut; Špeter: Zavod za slovensko izobraževanje, 2004.

Puren, Christian. $\gg$ La problematique de la formation dans le contexte actuel de l'écleti- sme méthodologique.« LEND, posebna številka, Modena: Lend. (1996): I 4-27.

Rasom, Olimpia, ur. Info project : designing a training model for teachers working in multilingual areas with minority language. Part I, The research and the European training model. Bolzano: Istitut Pedagogich Ladin, 2007.

Smernice za vključevanje otrok priseljencev $v$ vrtec in šole (Ljubljana: Zavod RS za šolstvo 2012). Dostopno na: Http://eportal.mss. edus.si/msswww/programi2ors/programi/ media/pdf/smernice/cistopis_Smernice_ vkljucevanje_otrok_priseljencev.pdf.

Zorman, Anja in Nives Zudič Antonič. »Prvi koraki pri razvijanju medkulturnega zavedanja: seznanjanje $\mathrm{z}$ jezikom okolja na narodnostno mešanih območjih v Republiki Sloveniji.« Sodobna pedagogika, letn. 57 (2006): 232-245.

Zorman, Anja in Nives Zudič Antonič. »Pojmovanje medkulturne vzgoje med učitelji in njihova medkulturna občutljivost.« V Vzgajati k različnosti: interdisciplinarna primerjalna raziskava med Italijo in Slovenijo, ur. Norina Bogatec in Nives Zudič Antonič, IOI-I 8 . Koper: Univerza na Primorskem, Znanstveno-raziskovalno središče, Univerzitetna založba Annales, 2014.

Zudič Antonič, Nives. »Za različno vizijo in zaznavo sveta: jeziki, kulture in medkulturnost.« Šolsko polje, letn. 19, št. 3/4, (2008): III-I29.

Zudič Antonič, Nives. »Razvijanje medkulturne in sporazumevalne zmožnosti pri pouku tujega/drugega jezika v Sloveniji.« V Brez spopada: kultur, spolov, generacij, ur. Veronika Tašner et al., 29-42. Ljubljana: Pedagoška fakulteta, 2009.

Zudič Antonič, Nives. »Italijanščina kot prvi jezik v manjšinskih šolah Slovenske Istre.« V Izobraževanje za dvojezičnost v kontekstu evropskih integracijskih procesov: ućinkovitost dvojezičnih modelov izobraževanja $v$ etnično mešanih okoljih Slovenije, ur. Lucija Čok, 75-88. Koper: Univerza na Primor- 
skem, Znanstveno-raziskovalno središče, Založba Annales, 2009.

Zudič Antonič, Nives. »Vzgoja za dvojezičnost in večjezičnost.« V Slovenski jezik v stiku: sodobne usmeritve večjezičnega in manjsinskega izobraževanja, ur. Sonja Novak-Lukanovič in Vesna Mikolič, 52-70.Ljubljana: Društvo za uporabno jezikoslovje Slovenije, $2011 \mathrm{ra}$.

Zudič Antonič, Nives. »L'educazione letteraria in prospettiva interculturale.«V Studi interculturali: interferenze linguistiche, didattiche e culturali nel territorio istroquarnerino, ur. Rita Scotti Jurić e Tarita Štokovac, II3-I 46. Pola: Univerza Juraj Dobrila, Oddelek za italijanski jezik, 20 ıb.

Zudič Antonič, Nives in Metka Malčič. »Razvijanje medkulturne sporazumevalne zmožnosti pri poučevanju tujega jezika.« V Bližina drugosti: poti do medkulturne sporazumevalne zmožnosti $=$ towards intercultural communicative competence in Europe and beyond, ur. Lucija Čok, 31I-32I. Koper: Univerza na Primorskem, Znanstveno-raziskovalno središče, Založba Annales, 2006.

Zudič Antonič, Nives in Metka Malčič. Il vicino diverso : percorsi di educazione interculturale di lingua italiana $=$ Bližina drugosti: poti italijanskega jezika do medkulturne komunikacije. Koper: Znanstveno-raziskovalno središče, Založba Annales, $2007 \mathrm{a}$.

Zudič Antonič, Nives in Metka Malčič. »Bisogni emersi.« V Progetto Info: La ricerca e il modello di formazione europeo, ur. Olimpia Rasom, 88-92. Bolzano: Istitut Pedagogich Ladin, 2007b.

Zudič Antonič, Nives in Anja Zorman. »Predstavitev pogledov otrok in staršev iz različnih držav na nekatere vidike učenja in poučevanja manjšinskih jezikov.« Šolsko polje, I7/I-2, (2006): I27-I 42.

Zudič Antonič, Nives in Anja Zorman. »Izobraževanje učiteljev in medkulturna vzgoja.« V: Vzgajati $k$ različnosti: interdisciplinarna primerjalna raziskava med Italijo in Slovenijo, ur. Bogatec, Norina in Ni- ves Zudič Antonič, 197-212. Koper: Univerza na Primorskem, Znanstveno-raziskovalno središče, Univerzitetna založba Annales, $2014 a$.

Zudič Antonič, Nives in Anja Zorman, ur. Prepletanja: didaktični priročnik za medkulturno vzgojo brez meja. Koper: Univerza na Primorskem, Znanstveno-raziskovalno središče, Univerzitetna založba Annales, 20I4b. Dostopno na spletni strani: Http:// www.eduka-itaslo.eu/.

Weinreich, Uriel. Languages in Contact: Findings and Problems. Paris-New York: Mouton Publishers - The Hague, 1979.

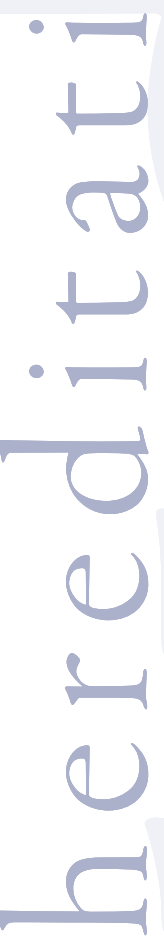

